\title{
Histopathological investigation of onychomycosis frequency in psoriatic nails using periodic acid-Schiff staining
}

\author{
Psoriasisli tırnakta onikomikoz sıklığının periodik asit-Schiff boyama ile histopatolojik \\ olarak araștırılması
}

\section{Mavișe Yüksel, ๑ Ali Balevi, ๑ Mustafa Özdemir, ๑ Illknur Türkmen*, ๑ Alkım Ünal Çakıter, ๑ Esra Saraç, ๑ Mehmet Ünal**, ๑ Elif Çalıș*}

İstanbul Medipol University Faculty of Medicine, Department of Dermatological and Venereal Diseases; *Department of Pathology, İstanbul, Turkey **Selçuk University Faculty of Medicine, Department of Dermatological and Venereal Diseases, Konya, Turkey

\begin{abstract}
Background and Design: Psoriasis nail involvement is clinically similar to onychomycosis. Especially subungual hyperkeratosis and onycholysis are also common in both nail diseases. These two diseases may be seen separetely or together. The aim of this study was to compare the frequency of onychomycosis with control group in patients with psoriasis and to determine the factors predisposing to onychomycosis in patients with psoriasis.

Materials and Methods: The study included 43 patients with psoriasis who were admitted to istanbul Medipol Mega University, Clinic of Dermatology between 2017 and 2018 and 43 control patients who did not have psoriasis and had nail dystrophy. Participants who received systemic corticosteroid, methotrexate, cyclosporine, and systemic antifungal treatment 4 months ago and who received topical antifungal treatment 4 weeks ago were excluded from the study. The nail samples were examined histochemically with periodic acid-Schiff (PAS) stain. Results: Onychomycosis was detected in 11 patients with psoriasis (25.6\%) (hand and/or foot), while in 17 patients (39.5\%) in control group. There was no statistically significant difference between two groups $(p=0.170)$. In control group, toe nail onychomycosis was significantly higher than in the psoriatic group $(p=0.024)$. It was noteworthy that onychomycosis was statistically significant in the group with high educational level and low Psoriasis Area Severity Index ( $p<0.05$ and $p=0.021$, respectively).

Conclusion: In this study, we determined that nail psoriasis is not a risk factor for onychomycosis by histopathological examination of fungal samples with PAS staining.

Keywords: Onychomycosis, psoriasis, periodic acid-Schiff
\end{abstract}

\section{Öz}

Amaç: Psoriazis tırnak tutulumu klinik olarak onikomikoza benzer. Özellikle; subungual hiperkeratoz ve onikoliz iki tırnak hastalığında da yaygın olarak görülür. Bu iki hastalık ayrı ayrı olabileceği gibi birlikte de olabilir. Bu çalışmanın amacı, psoriazisli hastalarda onikomikoz sıkıı̆ının kontrol grubuyla karşılaştıııması ve psoriazisli hastalarda onikomikoza predispozan faktörlerin tespitinin sağlanmasıdır.

Gereç ve Yöntem: Çalışmaya 2017-2018 yılları arasında i̇stanbul Medipol Mega Üniversitesi, Dermatoloji Kliniği'ne başvuran 43 psoriazisli hasta ve 43 psoriazisi olmayan ve tırnak distrofisi olan kontrol grubu alındı. Dört ay önce sistemik kortikostreoid, metotreksat, siklosporin ve sistemik antifungal tedavi almış, 4 hafta önce topikal antifungal tedavi almış katılımıılar çalışmadan çıkartıldı. Alınan tırnak örnekleri periyodik asit-Schiff (PAS) boyası ile histokimyasal olarak incelendi.

Bulgular: Psoriazisi olan 11 hastada $(25,6)$ (el ve/veya ayak) onikomikoz tespit edildirken, kontrol grubunda 17 hastada $(\% 39,5)$ onikomikoz tespit edildi. Her iki grup arasında istatistiksel anlamlı fark yoktu $(p=0,170)$. Kontrol grubunda ayak tırnak onikomikozu psoriatic gruba göre

Address for Correspondence/Yazışma Adresi: Mavişe Yüksel MD, İstanbul Medipol University Faculty of Medicine, Department of Dermatological and Venereal Diseases, Istanbul, Turkey

Phone: +90 5053901779 E-mail: mavisey107@gmail.com Received/Geliş Tarihi: 01.02.2020 Accepted/Kabul Tarihi: 28.04.2020 ORCID: orcid.org/0000-0002-0011-7570

(C) Copyright 2020 by Turkish Society of Dermatology and Venereology

Turkderm - Turkish Archives of Dermatology and Venereology published by Galenos Yayınevi. 
anlamlı dercede yüksekti ( $p=0,024)$. Psoriazis hasta grunda eğitim düzeyi yüksek olan ve Psoriazis Alan Şiddet indeksi değeri düşük olanlarda onikomikozun istatistiksel olarak anlamlı derecede fazla olması dikkat çekiciydi (sırasıyla; $p<0,05 ; p=0,021$ )

Sonuç: Biz bu çalışmada, tırnak psoriazisinin onikomikoz için bir risk faktörü olmadığını, mantar örneklerinin PAS boyama ile histopatolojik olarak incelenmesi ile tespit ettik.

Anahtar Kelimeler: Onikomikoz, psoriazis, periyodik asit-Schiff

\section{Introduction}

From past to present, it is known that the disorders of the nail structure cause social withdrawal by creating a feeling of shame. In $40-45 \%$ of patients with psoriasis, nail involvement occurs. Without skin involvement, only $5 \%$ of patients present with nail involvement. Nail involvement in patients with psoriatic arthritis reaches $87 \%$. In psoriasis, classical nail lesions occur with the involvement of the nail bed and nail matrix. Involvement of the nail matrix consists of pitting, leukonychia, red spots in the lunulae, and crumbling of the nail plate, while onycholysis, splinter hemorrhage, oil stain, and subungual hyperkeratosis are seen in the nail bed. The most common finding is pitting, followed by onycholysis ${ }^{1}$. Onychomycosis is the most common nail disease and comprises up to $50 \%$ of all nail diseases ${ }^{2-4}$. In the development of onychomycosis, male sex, advanced age, systemic diseases, such as psoriasis and diabetes, immunosuppression, peripheral artery diseases, presence of onychomycosis in the family, especially in parents and children, and swimming constitute risk factors for this disease ${ }^{5}$.

A review of articles published to date reveals that the prevalence of onychomycosis in psoriatic patients compared with healthy controls is controversial. The histochemical examination of nail specimens using periodic acid-Schiff (PAS) is much more sensitive than direct microscopy with potassium hydroxide $(\mathrm{KOH})$ and fungal culture analysis. This study is valuable since it is one of the very few studies in the literature that investigated the prevalence of onychomycosis in psoriasis by the histochemical staining of fungal specimens with PAS.

\section{Materials and Methods}

\section{Patients and clinical evaluation}

The study included 43 patients aged 18 to 60 years with psoriasis (20 males, 23 females) that presented to the dermatology outpatient clinic of İstanbul Medipol Mega University Hospital between 2017 and 2018, who had not received any systemic corticosteroid, methotrexate, cyclosporine or systemic antifungal treatment or topical antifungal therapy within the last four weeks, were not pregnanat, and did not have liver or kidney diseases. In cases of nail involvement, only patients with pitting and/or striation were excluded from the study. The control group consisted of 43 age- and sex-matched individuals with no history of psoriasis but with nail findings creating suspicion of onychomycosis. In the psoriasis group, samples were obtained from a maximum of two nails belonging to the index finger and/or toe with signs of psoriasis other than pitting and/or striation. In the control group, samples were collected from a maximum of nails of the index finger and/or toe suspected to have onychomycosis due to the presence of subungual hyperkeratosis, onycholysis, leukonychia, and/or crumbling findings. The age, sex, Psoriasis Area Severity Index (PASI), Nail Psoriasis Severity Index (NAPSI), body mass index (BMI), education level, duration of nail involvement, type of psoriasis, presence of psoriatic arthritis, and presence of onychomycosis in the family were recorded for each patient. The severity of nail involvement was determined according to the NAPSI ${ }^{6}$. The severity of skin disease was scored and recorded according to PASI. This study was approved by the Ethics Committee of İstanbul Medipol Mega University Hospital (approval number: 10840098-604.01.01-E.44197, date: 29/11/2017). Informed consent was obtained from each patient. The study was planned in accordance with the principles of the Helsinki Declaration.

\section{Collection of nail samples and histopathological evaluation by PAS staining}

The first step of nail collection was to wipe the nail with alcohol to remove any contamination. The abnormal nail was proximally cut, and the nail bed and lower part of the nail plate were scraped with a $1-2 \mathrm{~mm}$ curette. The samples taken from the patient and control groups were kept in 10\% neutral buffered formaldehyde for 24 hours, at the end of which they were placed in $15 \% \mathrm{KOH}$ solution. Under the supervision of a technician, the sample was checked at 15 minute intervals. After sufficient softening was achieved, the samples were placed in cassettes and washed under the tap. In the following stage, tissue processing was performed using a Sakura Tissue-Tek VIP 6 automatic tissue processor. This procedure was completed using a Sakura Tissue-Tek TEC 5 embedding station. Then, hematoxylin and eosin staining was undertaken with a Sakura Tissue-Tek prisma automatic stainer. PAS histochemistry staining was performed using a Roche Benchmark Special Stains histochemistry instrument and a PAS kit. The PAS-stained sections were examined under light microscopy. All sections on the slide were examined, and the presence of fungal hyphae was considered as fungal infection (Figure 1b).

\section{Statistical Analysis}

The data were collected by a physician in the relevant clinic, transferred to Microsoft Excel program, edited, cleaned, and made suitable for analysis. The Mann-Whitney $U$ test, Spearman correlation and chi-

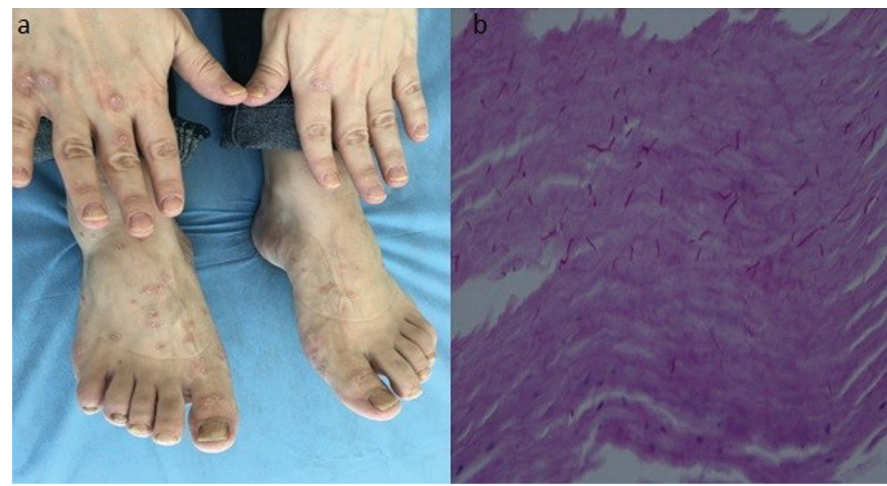

Figure 1. a) A psoriasis case presenting with onychomycosis in hand and foot nails, b) demonstration of fungal hyphae by the histopathological examination of the nail sample using periodic acidSchiff stain 
square tests were used in the analyses. The data analysis was performed using the SPSS (IBM SPSS Statistics, v. 25.0). A p-value of 0.05 was accepted as statistically significant.

\section{Results}

Of the 43 psoriasis patients included in the study, 23 (53.5\%) were female and 20 (46.5\%) were male (Table 1). The control group included 43 age- and sex-matched individuals. The median age of the patients in the psoriasis group was 40, and their mean BMI was 26.8. In this group, the mean duration of disease was 9.7 years, while that of nail involvement was 4.9 years, and the mean total NAPSI was evaluated as 24.7 (mean hand NAPSI: 12; mean foot NAPSI: 12.7) and the mean PASI as 9.4. In the psoriasis group, the most common fingernail finding was pitting ( $n=32,80 \%)$ and the most common toenail finding was subungual hyperkeratosis ( $n=32,97 \%$ ) (Table 2, Figure 1a).

The prevalence of onychomycosis (index finger and/or toe nail) was calculated as $25.6 \%$ in the psoriatic group and $39.5 \%$ in the control group (Table 3 ). When the presence of onychomycosis in finger nails was examined, no statistically significant difference was found between the patient and control groups ( $p>0.05$ ). However, in the examination of toe nail onychomycosis, a significant difference was found between the two groups $(p=0.024)$. Toe nail onychomycosis was significantly

\begin{tabular}{|c|c|}
\hline Variable & n (\%) \\
\hline \multicolumn{2}{|l|}{ Psoriasis patient } \\
\hline Female & $23(53.5 \%)$ \\
\hline Male & $20(46.5 \%)$ \\
\hline \multicolumn{2}{|l|}{ Education level } \\
\hline Four years & $9(20.9 \%)$ \\
\hline Eight years & $17(39.5 \%)$ \\
\hline 16 years & $17(39.5 \%)$ \\
\hline \multicolumn{2}{|l|}{ Family history of onychomycosis } \\
\hline Absent & $35(81.4 \%)$ \\
\hline Present & $7(16.3 \%)$ \\
\hline Information not available & $1(2.3 \%)$ \\
\hline \multicolumn{2}{|l|}{ Psoriatic arthritis } \\
\hline Absent & $13(30.2 \%)$ \\
\hline Present & $30(69.8 \%)$ \\
\hline \multicolumn{2}{|l|}{ Type of psoriasis } \\
\hline Guttate & $8(18.6 \%)$ \\
\hline Plaque & $33(76.7 \%)$ \\
\hline Palmoplantar & $2(4.7 \%)$ \\
\hline \multicolumn{2}{|l|}{ Presence of onychomycosis } \\
\hline No onychomycosis & $32(74.4 \%)$ \\
\hline Onychomycosis present & $11(25.6 \%)$ \\
\hline Fingernail onychomycosis & $6(14.0 \%)$ \\
\hline Toenail onychomycosis & $2(4.6 \%)$ \\
\hline Fingernail and toenail onychomycosis & $3(7.0 \%)$ \\
\hline
\end{tabular}

higher in the control group than in the psoriatic group (Table 4, Figure 2). The relationship between joint involvement and finger and toe nail onychomycosis was examined by the chi-square test, and no significant relationship was observed ( $p>0.05)$

There was no difference in NAPSI between the psoriasis patients with and without onychomycosis $(p=0.450)$. However, the incidence of onychomycosis in psoriasis patients was significantly higher in those with a low PASI ( $p=0.021$ ) (Table 5). When the education level of psoriasis patients and the presence of onychomycosis were examined together a significant relationship was found between the two parameters $(p<0.05)$. According to the results, the rate of onychomycosis increased as the education level increased (Table 6, Figure 3).

\section{Table 2. Common nail findings of the psoriasis group}

\begin{tabular}{|l|l|}
\hline Variable & n (\%) \\
\hline Fingernail finding & $32(80.0 \%)$ \\
\hline Onycholysis & $12(30.0 \%)$ \\
\hline Subungual hyperkeratosis & $12(30.0 \%)$ \\
\hline Oil stain & $5(12.5 \%)$ \\
\hline Leukonychia & $2(5.0 \%)$ \\
\hline Increased striation & $1(2.5 \%)$ \\
\hline Toenail finding & \\
\hline Subungual hyperkeratosis & $32(97 \%)$ \\
\hline Onycholysis & $4(12.1 \%)$ \\
\hline Leukonychia & $2(6.1 \%)$ \\
\hline n: number of patients & \\
\hline
\end{tabular}

Table 3. Distribution of onychomycosis in the psoriasis and control groups and the results of the MannWhitney U test

\begin{tabular}{|l|l|l|}
\hline Variable & n (\%) & p \\
\cline { 1 - 1 } Psoriasis group & \multirow{2}{*}{$* 0.170$} \\
\cline { 1 - 1 } No onychomycosis & $32(74.4 \%)$ & \\
\cline { 1 - 2 } Onychomycosis present & $11(25.6 \%)$ & \\
\cline { 1 - 2 } Control group & $26(60.5 \%)$ & \\
\cline { 1 - 2 } No onychomycosis & $17(39.5 \%)$ & \\
\cline { 1 - 2 } Onychomycosis present & \\
\cline { 1 - 2 } *Significant at the level of $0.05, \mathrm{n}$ : number of patients & \\
\hline
\end{tabular}

Table 4. Comparison of fingernail and toenail onychomycosis (results of the Mann-Whitney U test)

\begin{tabular}{|l|l|l|}
\hline Variable & $\begin{array}{l}\text { Fingernail } \\
\text { onychomycosis }\end{array}$ & $\begin{array}{l}\text { Toenail } \\
\text { onychomycosis }\end{array}$ \\
\hline Control group & $1.20(20) \pm 0.41$ & $1.39(38) \pm 0.50$ \\
\hline Psoriasis group & $1.23(40) \pm 0.42$ & $1.15(33) \pm 0.36$ \\
\hline Total & $1.22(60) \pm 0.42$ & $1.28(71) \pm 0.45$ \\
\hline$p$ & 0.826 & $0.024^{*}$ \\
\hline *Significant at the level of 0.05 & \\
\hline
\end{tabular}




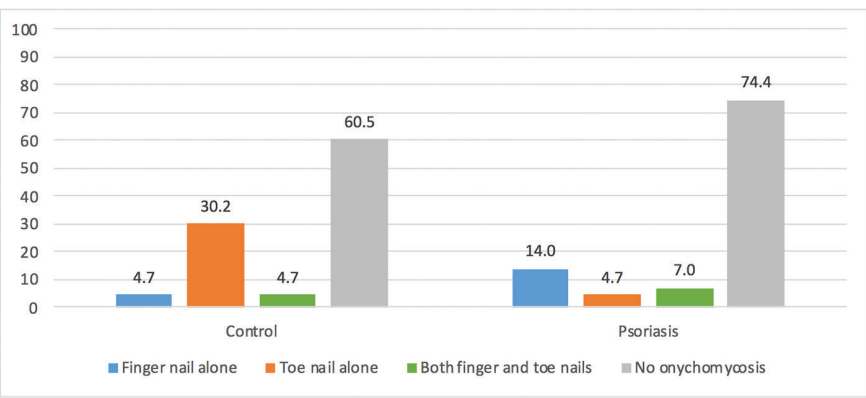

Figure 2. Distribution of finger and/or toe nail onychomycosis in the psoriasis and control groups (\%)

\section{Discussion}

In healthy nails, the compact orthokeratotic nail plate provides a protective barrier against fungal infections, and the disruption of this layer in diseases, such as nail psoriasis suggests an increased tendency of the nail to fungal invasion. On the contrary, the presence of rapid nail turnover in psoriasis patients has theoretically created the perception that it may be a defense against dermatophyte invasion ${ }^{7}$. In addition, the coexistence of onychomycosis with nail psoriasis can increase the severity of nail involvement based on the Koebner phenomenon and cause treatment failure; therefore, detection of onychomycosis is extremely important in patients with psoriasis ${ }^{8}$.

The clinical differentiation of onychomycosis and nail psoriasis is often difficult. Clinically, subungual hyperkeratosis and onycholysis are seen in both diseases. The current laboratory methods for diagnosing fungal infections of the nail are the direct microscopic examination of the nail sample using $\mathrm{KOH}$ and fungal culture analysis ${ }^{9,10}$. However, when using these methods, false negative results are seen in approximately $30 \%$ of patients, which leads real infectious cases being overlooked. False negative results may be obtained due to insufficient material collection for the direct microscopic examination using $\mathrm{KOH}$, not melting or spreading the material properly, and not examining all the areas under microscope ${ }^{11}$. Another point to consider is that the false-positive rates are high since textile fibers, air bubbles and fat droplets mimic a fungal structure under direct microscopy with $\mathrm{KOH}$. Culture analysis is also not an ideal screening method for the diagnosis of onychomycosis due to its low sensitivity rate, high cost, and long waiting time; however, it has high superiority in determining the causative agent ${ }^{11}$. It is known that the histopathological examination of the nail by PAS staining is more sensitive and has a higher negative predictive value than the classical methods of $\mathrm{KOH}$ and fungal culture ${ }^{9,12}$. Furthermore, other favorable characteristics of PAS staining making it superior to the two classical methods include producing results within a short time like 24 hours, allowing preparations to be stored and used in retrospective diagnoses, and assisting clinicians diagnose diseases causing onychodystrophy, such as psoriasis ${ }^{11}$. Nevertheless, PAS staining is not used in routine clinical practice because it is an expensive method. Considering all the advantages of the method, we chose to perform histopathological examination by PAS staining in the current study.

In the literature, there are conflicting results in studies on nail fungus in psoriasis patients. There are studies showing that onychomycosis is seen at a high rate in psoriatic patients, as well as those revealing less or no difference. In a study of 113 psoriatic patients, Leibovici et al. ${ }^{13}$ reported that toe nail onychomycosis was significantly higher (47.6\%) compared to normal healthy controls. Larsen et al. ${ }^{8}$ found onychomycosis at a higher rate in psoriasis $(21.5 \%)$ than the normal population, but did not detect a statistically significant difference. In a study conducted with 168 psoriatic patients, Kaçar et al. ${ }^{14}$ determined that psoriatic nails did not pose an increased risk of onychomycosis. Salomon detected the prevalence of onychomycosis as $18 \%$ in the psoriatic group, which was lower compared to the normal population ${ }^{15}$. Tekin et al. ${ }^{16}$ evaluated 120 patients with psoriasis and did not find a significant difference in terms of onychomycosis. In a study including 100 psoriasis patients, Koçak et al. ${ }^{17}$ did not find a statistically significant difference in the patient group compared to the healthy control group in terms of the dermatophyte infection of the nail. In all the studies mentioned above, the detection of fungal elements was performed mycologically. Natarajan et al. ${ }^{18}$ conducted a study with 72 psoriasis patients in India in 2009 and evaluated nail samples using PAS staining and histopathological analysis in patients with a strong clinical suspicion of onychomycosis but negative $\mathrm{KOH}$ and fungal culture findings. In the same study, the authors found the coexistence of nail fungus in $47.9 \%$ of the psoriatic patients. In another study, the histological evaluation of nail plate samples by PAS staining was used as a complementary method in cases where $\mathrm{KOH}$ and fungal culture were negative but there was a clinically strong suspicion of a fungal infection ${ }^{16}$.

In this study, according to the histopathological examination by PAS staining, the prevalence of fingernail onychomycosis was similar in psoriatic and non-psoriatic patients, but toenail onychomycosis was significantly higher in the control group compared to the psoriasis group. In addition, the prevalence of onychomycosis was higher in the group with a higher level of education, which can be explained by the increased awareness of these patients, leading them to consult a dermatologist in the presence of suspicious symptoms or their higher tendency to have hobbies, such as swimming, tennis, skiing, and playing instruments that may cause trauma to the nail. In addition, the

Table 5. Comparison of the psoriatic patients with and without onychomycosis in terms of NAPSI scores (results of the Mann-Whitney U test)

\begin{tabular}{|l|l|l|l|l|}
\hline Variable & PASI & Total NAPSI & Fingernail NAPSI & Toenail NAPSI \\
\hline No onychomycosis & $10.83(30) \pm 7.62$ & $25.72(32) \pm 12.51$ & $10.97(32) \pm 8.00$ & $14.59(32) \pm 12.35$ \\
\hline Onychomycosis present & $5.82(11) \pm 2.82$ & $22.09(11) \pm 11.77$ & $15.18(11) \pm 13.25$ & $7.18(11) \pm 8.21$ \\
\hline Total & $9.49(41) \pm 7.01$ & $24.79(43) \pm 12.29$ & $12.05(43) \pm 9.62$ & $12.70(43) \pm 11.80$ \\
\hline$p$ & 0.021 * & 0.450 & 0.631 & 0.068 \\
\hline *Significant at the level of 0.05. PASI: Psoriasis Area Severity Index, NAPSI: Nail Psoriasis Severity Index & \\
\hline
\end{tabular}




\begin{tabular}{|c|c|c|c|}
\hline Education level & $\begin{array}{l}\text { No } \\
\text { onychomycosis }\end{array}$ & $\begin{array}{l}\text { Onychomycosis } \\
\text { present }\end{array}$ & $\mathbf{p}$ \\
\hline Four years & $8(88.9 \%)$ & $1(11.1 \%)$ & \multirow{4}{*}{$0.000^{*}$} \\
\hline Eight years & $15(88.2 \%)$ & $2(11.8 \%)$ & \\
\hline 16 years & $9(52.9 \%)$ & $8(47.1 \%)$ & \\
\hline Total & $32(74.4 \%)$ & $11(25.6 \%)$ & \\
\hline \multicolumn{4}{|c|}{ * Significant at the level of 0.05} \\
\hline
\end{tabular}

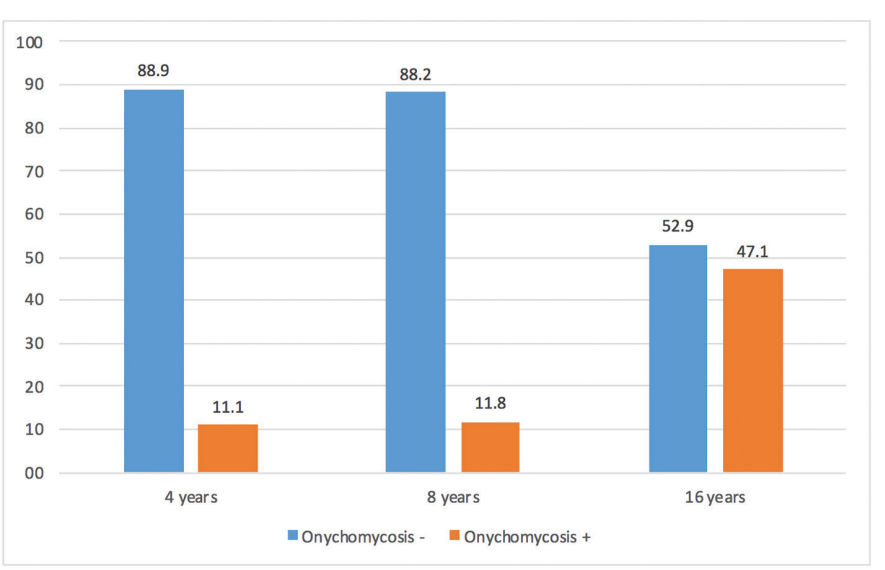

Figure 3. The relationship between education level and onychomycosis in psoriasis patients (\%)

high prevalence of onychomycosis in psoriasis patients with low PASI supports the idea that psoriasis protects patients from nail fungus.

\section{Study Limitations}

In this study, the evaluation of onychomycosis was performed only by PAS staining, and not by $\mathrm{KOH}$ or fungal culture. In future studies, the screening of search onychomycosis in psoriasis patients can be undertaken using all three methods.

\section{Conclusion}

Since psoriasis treatment can worsen a possible case of overlooked onychomycosis, it is very important to detect onychomycosis in psoriatic nails before starting psoriasis treatment. For the detection of this condition, methods, such as $\mathrm{KOH}$ and fungal culture can be used; however, PAS staining should be considered in cases with a strong clinical suspicion.

\section{Ethics}

Ethics Committee Approval: This study was approved by the Ethics Committee of İstanbul Medipol Mega University Hospital (approval number: 10840098-604.01.01-E.44197, date: 29/11/2017) and conducted according to the principles of the Helsinki Declaration.

Informed Consent: Informed consent was obtained from each patient.
Peer-review: Externally peer-reviewed.

\section{Authorship Contributions}

Concept: M.Y., A.B., M.Ö., I.T., Design: M.Y., A.B., Supervision: M.Y., A.B., M.Ü., Materials: M.Y., I.T. Data Collection and/or Processing: M.Y., A.B., A.U.Ç., E.S., Analysis and/or Interpretation: I.T., E.Ç., Literature Search: M.Y., A.B., M.Ü., Writing: M.Y., Critical Review: A.B.

Conflict of Interest: The authors declared no conflict of interest.

Financial Disclosure: The authors declared that this study received no financial support.

\section{References}

1. Tan EST, Chong WS, Tey HL: Nail psoriasis: A review. Am J Clin Dermatol 2012;13:375-88.

2. Sigurgeirsson B, Baran R: The prevalence of onychomycosis in the global population: A literature study. J Eur Acad Dermatol Venereol 2014;28:148091.

3. Szepietowski JC, Salomon J: Do fungi play a role in psoriatic patient nails. Mycoses 2007; 50:437-42

4. Tabassum S, Rahman A, Awan S, et al: Factors associated with onychomycosis in nail psoriasis: a multicenter study in Pakistan. Int J Dermatol 2019;58:6728.

5. Sigurgeirsson B, Steingrímsson O: Risk factors associated with onychomycosis. J Eur Acad Dermatol Venereol 2004;18:48-51.

6. Rich P, Scher RK: Nail Psoriasis Severity Index: A useful tool for evaluation of nail psoriasis. Am Acad Dermatol 2003;49:206-12.

7. Klaassen KM, Dulak MG, van de Kerkhof PC, Pasch MC: The prevalence of onychomycosis in psoriatic patients: a systematic review. J Eur Acad Dermatol Venereol 2014;28:533-41.

8. Larsen GK, Haedersdal M, Svejgaard EL: The prevalence of onychomycosis in patients with psoriasis and other skin diseases. Acta Derm Venereol 2003;83:206-9

9. Reisberger EM, Abels C, Landthaler M, Szeimies RM: Histopathological diagnosis of onychomycosis by periodic acid-Schiff-stained nail clippings. $\mathrm{Br}$ Dermatol 2003;148:749-54

10. André J, Sass U, Richert B, Theunis A: Nail pathology. Clin Dermatol 2013;31:526-39.

11. Ceren E, Ekmekci T, Sakız D, Köşlü A, Bayraktar B. Onikomikoz tanısında kullanılan yöntemlerin karşışşıtıılması. Turkderm 2008;42:91-3.

12. Haghani I, Shokohi T, Hajheidari Z, Khalilian A, Aghili SR: Comparison of diagnostic methods in the evaluation of onychomycosis. Mycopathologia 2013; 175:315-21

13. Leibovici $V$, Hershko $K$, Ingber A, Westerman M, Leviatan-Strauss $N$, Hochberg M: Increased prevalence of onychomycosis among psoriatic patients in Israel. Acta Derm Venereol 2008;88:31-3.

14. Kaçar N, Ergin S, Ergin C, Erdogan BS, Kaleli I: The prevalence, aetiological agents and therapy of onychomycosis in patients with psoriasis: a prospective controlled trial. Clin Exp Dermatol 2007;32:1-5.

15. Salomon J, Szepietowski JC, Proniewicz A: Psoriatic nails: A prospective clinical study. J Cutan Med Surg 2003;7:317-21.

16. Tekin N, Koca R, Altınyazar H, Çınar S, Eştürk E, Muhtar ş: Nail involvement in patients with psoriasis and concomitant onychomycosis. Turkiye Klinikleri J Dermatol 2006;16:39-43.

17. Koçak A, Peksar $Y$, Karaslan A: The assessment of dermatophyte infections in psoriatic patients. Turkiye Klinikleri J Dermatol 2010;20:23-7.

18. Natarajan V, Nath AK, Thappa DM, Singh R, Verma SK: Coexistence of onychomycosis in psoriatic nails: A descriptive study. Indian J Dermatol Venereol Leprol 2010;76:723. 